UDC 001.4:81]:378.091.212=111～DOI: http://doi.org/10.31617/k.knute.2019-10-10.97

Nypadymka Alla,

$\mathrm{PhD}$ in Humanitarian Sciences, Kyiv National University of Trade and Economics, 19, Kyoto str., Kyiv, 02156, Ukraine

ORCID: 0000-0003-3267-6323

Researcher ID: A-9391-2019

\title{
PROFESSIONAL TERMINOLOGY IN THE LINGUISTIC TRAINING OF LAWSTUDENTS
}

The article deals with the issues of studying Latin by law students in nonlinguistic universities for special purposes. Lexical-morphological groups that create legal terms and were borrowed from the Latin language into Ukrainian, which have become a significant part of the professional language in the field of jurisprudence, are listed and reviewed. The article is illustrated by a number of Latin terms that provide substantial assistance to students in mastering special knowledge from a range of professional disciplines, facilitate the learning of a professional foreign language and contribute to enhancing the professional motivation of students and their 'early' professionalization.

Keywords: Latin, jurisprudence, Latin for lawyers, the value of the Latin language, professional-oriented approach.

\section{Нипадимка Алла. Професійна термінологія у лінгвістичній підготовці студентів-юристів.}

У статті розглядаються питання навчання студентів юридичних факультетів немовних вузів латинської мови для спеціальних иілей. Проаналізовано лексико-морфологічні групи, що створюють юридичні терміни, які перейшли з латинської мови до української, та стали значною частиною професійної мови в області юриспрудениії, а також способи словотворення. Стаття ілюстрована рядом латинських термінів, які надають істотну допомогу студентам в освоєнні дисциплін професійного циклу, полегшують вивчення іноземної мови професії, сприяють підвищенню професійної мотиваиії студентів і ранньої професіоналізаиії.

Ключові слова: латинська мова, юриспрудениія, латинська мова для юристів, значення латинської мови, професійно-орієнтований підхід. 
Relevance of the research topic. In the context of intensive intercultural communication, comparative studies of philological units of different languages in our case Latin and Ukrainian - are becoming increasingly relevant, because the presence of phraseologisms in the language is a testimony of the embodiment and reflection in the linguistic form of peoples' creative work, their outlook, and history. Therefore, it is extremely important to have a professionally oriented approach to teaching foreign languages to students because it provides advanced training and early professionalization. After all, the study of Latin in the first year of the university curriculum is preceded by the study of special disciplines, and the substantive content of such training enriches the future specialist with new knowledge.

Moreover, «Today, it is often not enough for lawyers to be familiar only with their own language. They need to cooperate with foreign colleagues. If they come from the smaller linguistic zones, they have to use a foreign language for legal purposes. This requires a long training process. General familiarity with foreign legal languages can accelerate and promote this process. Lawyers with an overall picture of the history, structure, and basic vocabulary of a foreign legal language are better placed to learn more easily and rapidly the particular terminology and style of this language in the field of their specialism (e.g., royalties, consumer law)» (Heikki E.S. Mattila, 2016: 22).

Analysis of recent research and publications. The importance of learning Latin and using it in the process of professionally oriented foreign language communication is being explored by scientists from around the world. In particular, it was studied in the United States by Robert G. Natelson, Steven L. Emanuel, J. Russell VerSteeg, Peter R. Marcleod, in Russia by Sidakova N. V., Kachalkin A. A., Marshaliuk N. V., Ulyanova I. L. In Ukraine the importance of Latin in the process of intercultural communication was explored by Vorona I. I.; the general cultural importance of Latin and the importance of introducing it in the context of modernization of general secondary education systemin Ukraine were explored by Sutula O.V.; the importance of Latin as an integral part of the training system for lawyers - by Rybachok S. M.; features of teaching Latin for students who study agrobiological sciences were investigated by S. P. Shevchenko. All researchers point out the importance of studying Latin for modern students of various professional fields and point out its impact on the English language.»Today the basics of Latin grammar, special vocabulary and the basics of Greek and Latin word formation contributes to professional terminological competence of a specialist as well as raises his or her professional prestige» (Vorona, 2015: 78).

At the same time «many of today lawyers lack the necessary qualifications for a linguistic grasp of Latin expressions and maxims: they do not read ordinary Latin. This means that they are unprepared to understand an expression or a maxim written in a 
form that even slightly differs from one learned by heart. If, for example, a lawyer with no command of ordinary Latin has only learned the expression nudum pactum by heart, then he is not capable of recognizing the form nudopacto. Understanding legal Latin is also made more difficult by the fact that it is often used as a sort of code, impossible to decode by purely language means. This use as a code is especially typical of common-law Latin. Very often, the first word (or the first two or three words) of an old Latin sentence may be used to express a legal notion» (Heikki E.S. Mattila, 2016: 192).

In the light of previous research, it is recognized that knowledge and qualification are becoming priority values in the age of globalization. Therefore, we illustrate our research with a number of Latin terms that provide significant assistance to students in the development of professional disciplines, facilitate the learning of a foreign language for professional purposes, enhance students' professional motivation and early professionalization.

Statement of problem. In recent years there has been a tendency for particular languages in educational institutions that train highly qualified lawyers. Therefore, in order to prepare for changes in the demand for multi-language skills from modern companies, education will need to keep pace and keep up with the times. The ability to study languages from around the world will become increasingly important for future lawyers entering the field of law and for those having access to continuing professional development related to linguistic elements. Language skills will soon become as valuable and necessary as legal skills. Learning Latin for law students is a great preparation for learning and becoming fluent in one or more Romance languages. Thus, learning Latin is the starting point for learning six languages at the same time.

This article aims to show a high degree of phonetic, morphological affinity and similarity of lexical phenomena in the Ukrainian and Latin languages, which not only facilitates the study of Latin in particular, but also facilitates the process of its study by law students.

The theoretical backgrounds. According to the linguistic qualification, the Latin language belongs to the Romance group of the Indo-European family, which along with other language groups includes Slavic languages, including Ukrainian. Many phenomena of phonetics, morphology, syntax and vocabulary in the Ukrainian language become clearer when learning Latin as a related language, which had a parent language with the Slavic languages. The relationship between languages is particularly noticeable in vocabulary and phraseology. If we examine the historical path of the development of literary Latin, it becomes quite clear why the Latin language, which is called «dead language», maintains the status of an international language in jurisprudence, medicine, philology and other sciences and why the wordforming elements of Latin and ancient Greek are still widely used in the formation of new scientific terminology. The words «a term» and «terminology» become the key to understanding this phenomenon. 
A term (Latin: Terminus - boundary, limit, end) - a word or phrase that means a well-defined special concept of any branch of science, technology, art, social life, etc. (Ukrainian Dictionary: 11 volumes, 1979. Vol. 10: p. 88).

Terminology is the body of terms used with a particular technical application in a subject of study, profession, technology, art, or all terms of a given language, etc (Ukrainian Dictionary: 11 volumes, 1979. Vol. 10: p. 88).

As a rule, the formed words in legal scientific terminology, borrowed from Latin, are nouns. But they also have their source in other parts of speech, which in the process of word formation through affixation have become the basis for other significant parts of speech forming lexico-morphological groups of words.

First of all, it is necessary to mention Latin nouns in the nominative singular, which have passed into the Ukrainian language without changing the form and loss of generic endings, and have created set legal terms.

These are Latin nouns that denote a feminine and sometimes, masculine person or subject (in the names of professions) ending in -a and that retain the same characteristics and the same ending in -a.

Charta, ae $\mathrm{f} / \mathrm{carta} /$ - (sheet) letter or papyrus, book, document, map; legal charter, agreement.

Camera, aef - vault, vaulted, arched room, roof or ceiling, small boat roofed over with timber; legal -Investigator's office, camera investigation.

Nota, ae $\mathrm{f}$ - sign, letter, brand; legal - note, diplomatic correspondence.

Sentetia, aef - judgment, opinion; legal - judgment, sentence.

Persona, aem,f - mask, character, personality; legal - person, legal person.

Curia, aef - senate, meeting house, curia or division of Roman people, royal court; legal - law, legality.

The second group consists of masculine nouns ending in -us, -er, and neuter nouns in -um with an active unchanged noun ending, having lost zero ending and received the masculine category in the Ukrainian language.

Argumentum, i n - proof, evidence, fact, argument, conclusion, reason, basis; legal - the same meaning.

Apparatus, im - preparation, instruments, equipment, supplies, stock, splendour, pomp, trappings; legal — cadre, personnel.

Codicillus, i m - notepad, small log, writing tablets, patent, petition to Emperor, will or codicil; legal - addition to a will.

Compromissum,in -arbitration agreement, court, a deal between different parties where each party gives up part of their demand; legal - the same meaning.

Magistratus,im - magistracy, civil office, government official; legal government, power.

Nuntius,im - messenger, courier; legal - agent, intermediary. 
The third group consists of singular masculine and singular neuter Latin nouns in -us, -um in the nominative case of different declension ( 2 and 4 ), which have not lost their original endings and in Ukrainian have received the meaning of the masculine gender:

Versus,usm - line, verse; legal - confrontation of the parties (verso).

Casus,usm - fall, overthrow; legal - accident, chance, contingency, emergency, fatality, fortuity, happening, hazard, incident, occurrence.

Collegium, i n - (priests) college or board, orporation, brotherhood, fraternity, guild, colleagueship; legal - a group of officials with equal rank and power, the Supreme Court Collegium.

Consilium,in - debate, discussion, counsel, suggestion, diplomacy or strategy; legal - debate, discussion, deliberation, consultation, advice, decision, resolution, state council, senate.

Modus, us $\mathrm{m}$ - manner, mode, way, method, rule, rhythm; legal - means, way, kind, method, rule.

Socius,im - associate, companion, ally; legal - associate, consort, partner.

The fourth group of nouns is the thirddeclension masculine ending in -er, -or, which mean a person. They came into the Ukrainian language with the Latin endings in the nominative case and also denote a male person (in somecircumstances it might be a feminine noun) or a subject:

Auditor,orism - listener, pupil, student;legal - a person qualified to audit accounts; law firm engaged in such business (audit company).

Orator,oris $\mathrm{m}$ - speaker;legal - speaker; obsolete the claimant in a cause of action in chancery; in chancery, the party who files a bill calls himself in those pleadings your orator. Among the Romans, advocates were called orators.

Carcer,erism - prison, jail;legal - Prisoner Isolation Cell.

Censor, oris $\mathrm{m}$ - censor, magistrate for registration or census, censurer, critic, legal - mentor, judge.

A separate large group of legal terms consists of the third declension feminine nouns ending in -io, which have come into the Ukrainian language as feminine nouns, but have changed the ending to $-i$. These nouns are derived from verbs (supine form) and indicate the process of action:

Appellatio,onisf - name, term, legal - timely resort to an appropriate superior court, appeal to higher authority.

Compensation, onisf - compensation, to pay afull cost; legal - mutual repayment.

Relation, onisf - attribution, transference; legal - the report which the judges made of the proceedings in certain suits to the prince were so called; type of process, charges against plaintiff (counterclaim). 
Remissio, onisf - sending back, sending away, returning, releasing, forgiveness, remiss; legal - waiver, cancellation (terms).

Stipulation, onisf - stipulation, condition, agreement; legal - oral contract, consensual contract, the most important type of agreement.

Transgression, onisf - transition, reorder; legal - violation of law.

Analyzing these groups of nouns, we see: 1) feminine and masculine nouns of the first declension in -a, which came to the Ukrainian language with the preservation of the original form (note, person); 2) masculine and neuter nouns ending in -us, -er, -um of the second declension, that did not lose their original endings, acquired in Ukrainian the meaning of masculine gender (forum, consensus); 3) masculine nouns in -or, -er of the third declension with unchanged stem have in Ukrainian language the category of masculine (corpus, punishment cell); 4) feminine nouns in-or, -er of the third declension, that changed in Ukrainian their endingsin -ія, retained the feminine gender in the Ukrainian language.

A considerable number of nouns were formed in the Ukrainian language from Latin adjectives. Let us consider two varieties of nominalization of Latin adjectives. The first group includes adjectives of the first and second declensions ending in -us, -a, -um, that having lost the adjective endings, have come into the Ukrainian language as masculine or feminine nouns.

Absurdus,a,um - out of tune, discordant, absurd, nonsensical, out of place; legal absurdity, nonsense.

Vacuum, in - emptyspace, unoccupied, lonely; legal - legal vacuum, absence of legal norms.

Defectus, a, um - weak, powerless; legal - bad debt.

Duplicates, a, um - double, duplicate; legal - the second copy of the document having the same validity as the original.

Expertus, a, um - well-proved, tested, shown to be true; legal - the expert who carries out the examination.

The second group includes nominalized adjectives of the second class endingin $-\mathrm{al}$, -ar that lost their generic endings.

Electoralis,e - elective; legal - set of voters.

Singularis, e - alone, unique, single, one by one, singular, remarkable, unusual; legal - an exclusive right, a special rule for a special exception.

Criminalis, e - criminal (as opposite to civil), of, pertaining to crime, crimepolice; legal - criminal, criminal offense.

Libiralis, e - gracious, polite, generous, free; legal - a supporter of liberalism, a member of the liberal party, a supporter of the socio-political current, an essential feature of which is to advocate a peaceful reformist path of social transformation. 
The analyzed Latin adjectives are used in scientific terminology not only as nouns, but also as adjectives (liberal, public, electoral, nominal) with typical Ukrainian suffixes and endings.

The nominal parts of speech are not the only ones subject to nominalizing. Let us consider the Finite Forms of the latinverbs: 'credo' and 'veto' that are neuter nouns, don't have inflections (changes in the endings of words) and were formed from the verbs credere (to believe) and vetare (to forbid).

Credo, credidi, creditum, credere 3 - to believe, to borrow, to trust, to give credit, to think, to accept as true, to be sure; legal- belief, doctrine, dogma, main principle.

Veto, vetui, vetitum, vetare 1 - to forbid, to prohibit, to reject, to veto, to be an obstacle to, to prevent; modern meaning - veto rights of countries that are members of the UN Security Council. These nouns were formed from the form of the singular first person of the present tense.

Analysis of the above legal terms suggests an extremely high degree of affinity of phonetic, morphological and lexical phenomena in the Ukrainian and Latin languages. Therefore, constant analysis of lexical and grammatical structures, focus on the affinity of languages will greatly facilitate the conscious mastery of professional terminology and comprehension of complex material in Latin grammar and will enrich the vocabulary of the future specialist. It should be remembered that «different monolinguistic, bilingual and explanatory dictionaries of legal terms interpret differently certain concepts, and only the context and creative approach to the translation of the text result in adequate and correct translation» (Antoniuk, 2009:225).

Conclusions and prospects for further research. «For one not fortunate enough to study Latin while young, rectifying the deficiency is not easily accomplished. Acquiring Latin competency requires thousands of hours of hard work, rendered harder the older one becomes. For those who wish to be accurate constitutional analysts, I see no remedy over the short term other than laboring at the task for as long as it takes. One long-term solution should be obvious: Institutions of higher learning, including law schools, should insist on at least modest Latin competency among faculry teaching constitutional subjects or offering constitutional commentary. Trying to do a job without the proper tools can be ineffective, and may promulgate or perpetuate mistakes as to what the Constitution really means» (Robert G. Natelson, 2018:78).

Thus, the practical purpose of mastering professional terminology is the conscious ability to speak a scientific language, to confidently use the most commonly used and relatively simple language tools in all kinds of linguistic activity - speech, hearing, reading and writing. 


\section{REFERENCES}

1. Ahmad Rizal M. Y., A. C. Er, R. Zuliskandar, MohdFuad M. J., A. B. Junaidi, Muhammad Asri M. A.\& N. Lyndon. (2013). Occidentalism and Latin Language: The Lingua Franca of Knowledge. Asian Social Science. 2013. Vol. 9, No. 14. P. 50-54. URL: https://www.researchgate.net/publication/272775196_Occidentalism_and_ Latin_Language_The_Lingua_Franca_of_Knowledge

2. Antoniuk N. M. (2009). Mezhdunarodni tehnologii navchaniya pravnichoy terminologii uzmisti inozemnomovnogo perekladu [International technologies of teaching legal terminology in the content of foreign language translation]. Visnyk Akademii advokatury Ukrainy - Bulletin of the Academy of Advocacy of Ukraine. № 1(14). p. 222-227 [in Ukrainian].

3. Heikki E.S. Mattila (2016). Comparative Legal Linguistics: Language of Law, Latin and Modern Lingua Francas. 2nd edition. Routledge. 504 p.

4. Robert G. Natelson (2018). Why Constitutional Lawyers Need to Know Latin. The Federalist Society Revie. Vol. 19. P. 74-78. URL:https://fedsoc-cmspublic.s3.amazonaws.com/update/pdf/t7gcyMEPAec4bpK7UUunxVptVfyDd7aeQFfq M9KP.pdf

5. Slovnyk ukrainskoy movy: v 11 tomah / red. Rada: I. K. Bilodid (golova) ta inshy [Ukrainian Dictionary: 11 volumes / editorial board: I. K. Bilodid (a head) and other] (1979); Kyiv: Naukova dumka-Scientific Thought. Vol. 10. p. 88 [in Ukrainian].

6. Vilelmini Sosoni, Lucja Biel (2018).EU Legal Culture and Translation. International Journal of Language \& Law. Vol. 7. P. 1-7. URL:https://www. researchgate.net/publication/326065351_EU_Legal_Culture_and_Translation

7. Vorona I. I. (2015). The Latin language significance in the terminological competence formation of future doctors. Medychna Osvita-Medical Education. № 4. P. 78 .

8. Strandvick I. (2014). Is there Scope for A More Professional Approach to EU Multilingual Lawmaking? The Theory and Practice of Legislation. Vol. 2 (2). P. 211-228.

9. Strandvick I. (2015). On Quality in EU Multilingual Making. In Šarčević S. (ed.). Languageand Culture in EU law - Multidisciplinary Perspectives. P. 141-148. Farnham: Ashgate. 